\title{
TRANSLATION OF ENGLISH IDIOMATIC EXPRESSIONS IN ZOOTOPIA INTO INDONESIAN CONTEXT
}

\author{
Asti Ramadhani Endah Lestari \\ Universitas Indraprasta PGRI Jakarta \\ Jl. Nangka Raya, Jagakarsa, Kota Jakarta Selatan \\ asti.ramadhani@unindra.ac.id
}

\begin{abstract}
This study aimed at describing the process and result of translation of English idiomatic expressions in Zootopia into Indonesian context. This study used a descriptive qualitative method. The data were collected through observation. The researcher watched Zootopia while identifying the idiomatic expressions appeared in the movie. The idioms then were translated into Bahasa Indonesia by using various translation methods. The result of the study revealed that four English idiomatic expressions have the similar form and meaning with Bahasa Indonesia idioms. Many of the English idioms have the equal meaning of idiomatic expressions but appear in different forms. Other idioms do not have the idioms with equal meaning, thus they were translated by using free translation method. Finally, there is one English word adopted in Bahasa Indonesia since this word refers to a job that does not exist in Indonesian context, meter maid.
\end{abstract}

Keywords: Translation, idiomatic expressions, English, Bahasa Indonesia

\begin{abstract}
Abstrak : Penelitian ini bertujuan untuk mendeskripsikan proses dan hasil terjemahan idioma bahasa Inggris di film Zootopia ke dalam konteks bahasa Indonesia. Penelitian ini menggunakan metode deskriptif kualitatif. Teknik pengumpulan data yang dilakukan dalam penelitian ini adalah observasi. Prosedur penelitian yang dilakukan dalam penelitian ini adalah peneliti menonton zootopia sambil mengidentifikasi idiom yang muncul di film. Idiom-idiom itu kemudian diterjemahkan ke dalam Bahasa Indonesia dengan menggunakan berbagai metode terjemahan. Hasil penelitian menunjukkan bahwa empat ungkapan idiomat bahasa Inggris memiliki bentuk dan makna yang mirip dengan idiom Bahasa Indonesia. Banyak idiom bahasa Inggris yang memiliki padanan makna yang sama dengan idiom bahasa Indonesia tetapi muncul dalam bentuk lain. Idiom yang tidak memiliki padanan idiom di dalam bahasa Indonesia, sehingga diterjemahkan dengan menggunakan metode penerjemahan bebas. Terakhir, ada satu idiom bahasa Inggris yang diadopsi dalam Bahasa Indonesia karena idiom ini merujuk pada pekerjaan yang tidak ada dalam konteks Indonesia, yaitu meter maid.
\end{abstract}

Kata kunci: Penerjemahan, idiom, bahasa Inggris, bahasa Indonesia

\section{INTRODUCTION}

Translation has been regarded as a part of applied linguistics. House defined translation in two definitions (2014, p. 39). First, translation is the result of a linguistic-textual operation in which a text in one language is re-produced in another language. Second, whether both a linguistic and textual activity that involves the reproduction of a text written in one language into another language. The similar definitions proposed by Emzir (2015, p. 2). Emzir stated that translation has two terms. As a noun, translation is the result of the translation process. 
As a verb, translation is the process in which transferring a text from one form into another form of a language. Translation is the linguistic activity which involves the process of transferring a text into another form of languages. Translation

Emzir (2015, p. 4) divided translation into three types:

a. Interlingual translation. The process of translation from one language into another language. This type of translation is most widely known as the translation process in general.

b. Intralingual translation. The process of translation in the similar language. This type of translation involves paraphrasing and rewording.

c. Intersemiotic translation. The process of translation from one verbal sign into nonverbal signs. Examples of intersemiotic translation are translating from text into pictures and translating text into songs.

Translation covers a various range of topics such as political speeches, legal texts, subtitles, literary works, academic sources, and many more. Thus, Translation is considered as an interdisciplinary field. In consequences, a translator should not only master knowledge about language but also knowledge in relevant fields that $s /$ he is dealing with. Pamungkas (2015, p. 193) stated that translation is a process that can be viewed from multiple perspective such as linguistics, social, functional, etc.

In 1972, Holmes firstly proposed the term translation studies (Munday, 2001, p. 6). The focus of this study is to find the appropriate translation of English proverbs in 2016 cartoon movies.

Newmark in Nugraha (2016, p. 127) proposes eight methods of translation:

1. Word for word translation: this method maintains the original structure of the source language into the target language.

2. Literal translation: This method of translation focuses on the grammatical structure of the target language.

3. Faithful translation: this method replicates the contextual meaning of the source language into the contextual meaning of the target language.

4. Semantic translation: This method focuses on the meaning of the text. This method may perceive the same concept as the faithful translation.

5. Adaptation: This method focuses on the cultural aspects of the target language.

6. Idiomatic translation: This method transfers the intention of the source language by adjusting the colloquial expressions or idioms of the target language.

7. Communicative translation: This method transfers the message of the source language into acceptable expressions in the target language.

8. Free translation: This method focuses on the message and intention of the source language rather than its grammatical structure. This method allows paraphrasing the message from the source language into the target language. 
Talking about language we will always dealing about meaning because the essential item of language is meaning. Language defined as a system of arbitrary vocal symbols by means of which a social group co-operates (Bloch and Trager , 2012, p. 2 ). Gomez (2006, p. 50) suggests that, in spite of the publicity given to Chomsky's view, "the key concept of linguistic creativity has only been minimally dealt with in the specialized literature of linguistics". In semantics, linguists look for general rules about the relationship between form of word and sentences and meaning. Griffin (2006, p. 6) emphasized that when you do semantics, you are dealing with meaning and there is no context to consider.

In semantics, linguistics also needs to consider other branches of language. Hufford et.al (2007, p. 260) stated that semantic theory is a part of a larger enterprise, linguistic theory, which includes the study of syntax (grammar) and phonetics (pronunciation) besides the study of meaning. In analyzing meaning of a sentence, linguists need to know the structure of the sentence since different structures make different meanings.

Dealing with semantics, there are some sentences that have different meaning with the sentence itself such as idioms. Hufford (2007, p. 328) idiomatic expressions are multi word phrases whose overall meanings as idiosyncratic and largely unpredictable, reflecting speaker meanings that are not derivable by combining the literal senses of the individual words in each phrase. The meaning of idioms is called as figurative meaning. For example when we say "break your leg" doesn't mean that we ask a Translation of English Idiomatic Expressions in Zootopia Into Indonesian Context (Asti Ramadhani Endah Lestari) person to break his/her leg but we support them to do their best.

Idioms can also be found in cartoon movies. Candra and Lestari (2016, p. 100) found that the role of proverbs in conversation management script is to primarily to organized turn - taking behavior- in particular topic in spoken discourse. Idioms function to strengthen the character built in cartoon movie.

Langlots (2006, p. 4) stated that idioms are usually used in order to communicate more clearly and visually, to play with words, to be different, or to be amusing or witty. Idioms are part of daily live of people. Translating the idioms may be a tricky process for a translator. Bradeau (2012, p. 240) claimed that the major difficulties in the process of translations of idioms spring from the internal complexity that they display.

Based on the phenomena above, the researcher is interested in conducting a study entitled "Bahasa Indonesia Subtitle of English Idioms in Zootopia". The research question of this study is: idioms found in Zootopia?

\section{METHODOLOGY}

This research used a descriptive qualitative method focusing on socio-pragmatics study. This study aimed at analyzing the appropriate translations of idioms found in Zootopia. Therefore, this study involved the sociology and pragmatics field in translating the proverbs. Nugraha (2016, p. 128) stated that socio-
1. What are the appropriate translations of 
pragmatics concerns with the relationship between the participants involved in social activities and social factors including the consequences of the social actions in society.

The data were collected through observation. The procedure of the research is as follow:

a. The researcher watched Zootopia and found the idioms contained in the script.

b. The researcher analyzed the meaning of English idiomatic expressions found in Zootopia

c. The researcher investigated the appropriate translations of the idiomatic expressions found in Zootopia into Bahasa Indonesia.

\section{RESULTS}

The result of this research can be seen in the following table:

Table 3.1 Data Analysis of Idiomatic Expressions in Zootopia Cartoon Movie

\begin{tabular}{|c|c|c|c|}
\hline No & $\begin{array}{l}\text { Speech - } \\
\text { Act of } \\
\text { Idiomayic } \\
\text { expressions }\end{array}$ & $\begin{array}{l}\text { Meaning of } \\
\text { Idiomatic } \\
\text { Expressions }\end{array}$ & $\begin{array}{l}\text { Translation } \\
\text { in Bahasa } \\
\text { Indonesia }\end{array}$ \\
\hline 1. & $\begin{array}{l}\text { Before you } \\
\text { hit the } \\
\text { streets. }\end{array}$ & $\begin{array}{l}\text { Before start } \\
\text { working }\end{array}$ & $\begin{array}{l}\text { Sebelum } \\
\text { berangkat } \\
\text { kerja }\end{array}$ \\
\hline 2. & $\begin{array}{l}\text { Scorching } \\
\text { sandstorm. }\end{array}$ & Very hot day & $\begin{array}{l}\text { Hari yang } \\
\text { sangat panas }\end{array}$ \\
\hline 3. & $\begin{array}{l}\text { bunny } \\
\text { bumpkin }\end{array}$ & $\begin{array}{l}\text { An } \\
\text { unsophisticat } \\
\text { ed bunny, } \\
\text { not } \\
\text { intelligent or }\end{array}$ & $\begin{array}{l}\text { Anak } \\
\text { ingusan }\end{array}$ \\
\hline
\end{tabular}

\begin{tabular}{|c|c|c|c|}
\hline & & $\begin{array}{l}\text { interested in } \\
\text { culture }\end{array}$ & \\
\hline 4. & $\begin{array}{l}\text { One } \\
\text { thousand } \\
\text { foot fall. }\end{array}$ & $\begin{array}{l}\text { A } \\
\text { description } \\
\text { or view of } \\
\text { a situation or } \\
\text { problem that } \\
\text { provides ver } \\
\text { y general inf } \\
\text { ormation, } \\
\text { but no } \\
\text { details: }\end{array}$ & $\begin{array}{l}\text { Omong } \\
\text { kosong }\end{array}$ \\
\hline 5. & carrot baby & $\begin{array}{l}\text { Immature } \\
\text { bunny }\end{array}$ & $\begin{array}{l}\text { Anak } \\
\text { ingusan }\end{array}$ \\
\hline 6. & $\begin{array}{l}\text { Frigid ice } \\
\text { wall }\end{array}$ & $\begin{array}{l}\text { A taciturn } \\
\text { person }\end{array}$ & $\begin{array}{l}\text { Peti es / berat } \\
\text { bibir }\end{array}$ \\
\hline 7. & Filthy toilet & $\begin{array}{l}\text { Bathroom } \\
\text { dream }\end{array}$ & Bunga tidur \\
\hline 8. & fluffy butt & $\begin{array}{l}\text { A person } \\
\text { who is fat }\end{array}$ & $\begin{array}{l}\text { Bantet } \\
\text { Orang } \\
\text { gendut }\end{array}$ \\
\hline 9. & $\begin{array}{l}\text { fuzzy } \\
\text { bunny }\end{array}$ & $\begin{array}{l}\text { One who } \\
\text { refuse to } \\
\text { learn, refuse } \\
\text { to think, and } \\
\text { refuses to } \\
\text { consider the } \\
\text { possibility } \\
\text { that they } \\
\text { could } \\
\text { possibly ever } \\
\text { be wrong }\end{array}$ & Anak malas \\
\hline 10. & $\begin{array}{l}\text { - Really, it's } \\
\text { kind of a } \\
\text { proud- } \\
\text { scared }\end{array}$ & Really scary & $\begin{array}{l}\text { Sangat } \\
\text { menakutkan }\end{array}$ \\
\hline
\end{tabular}




\begin{tabular}{|c|c|c|c|}
\hline & combo & & \\
\hline 11. & $\begin{array}{l}\text { You played } \\
\text { cribbage } \\
\text { with a } \\
\text { weasel once }\end{array}$ & $\begin{array}{l}\text { Trust on a } \\
\text { liar }\end{array}$ & Mudah ditipu \\
\hline 12. & $\begin{array}{l}\text { Yeah, he } \\
\text { cheats like } \\
\text { there's no } \\
\text { tomorrow }\end{array}$ & $\begin{array}{l}\text { Cheats very } \\
\text { fast, in large } \\
\text { amounts and } \\
\text { without } \\
\text { thinking } \\
\text { carefully }\end{array}$ & Akal bulus \\
\hline 13. & $\begin{array}{l}\text { Don't lose } \\
\text { your key! }\end{array}$ & Lose the clue & $\begin{array}{l}\text { Jangan } \\
\text { sampai } \\
\text { hilang arah }\end{array}$ \\
\hline 14. & $\begin{array}{l}\text { Greasy } \\
\text { walls. }\end{array}$ & $\begin{array}{l}\text { A cheating } \\
\text { person }\end{array}$ & Penipu ulung \\
\hline 15. & $\begin{array}{l}\text { Rickety } \\
\text { bed. }\end{array}$ & $\begin{array}{l}\text { Feeble with } \\
\text { age }\end{array}$ & $\begin{array}{l}\text { Dimakan } \\
\text { usia }\end{array}$ \\
\hline 16. & $\begin{array}{l}\text {, you little } \\
\text { dickens! }\end{array}$ & $\begin{array}{l}\text { You little } \\
\text { devil }\end{array}$ & Anak nakal \\
\hline 17. & $\begin{array}{l}\text { And City } \\
\text { Hall is right } \\
\text { up } \\
\text { my tail to } \\
\text { find them }\end{array}$ & $\begin{array}{l}\text { City Hall is } \\
\text { urging me } \\
\text { intensely } \\
\text { to find them }\end{array}$ & pencarian \\
\hline 18. & $\begin{array}{l}\text { You } \\
\text { probably } \\
\text { forgot but, I } \\
\text { was } \\
\text { top of my } \\
\text { class at the } \\
\text { academy. }\end{array}$ & $\begin{array}{l}\text { Number one } \\
\text { student }\end{array}$ & $\begin{array}{l}\text { Bintang } \\
\text { kelas }\end{array}$ \\
\hline 19. & $\begin{array}{l}\text { So hit the } \\
\text { road! }\end{array}$ & $\begin{array}{l}\text { Start } \\
\text { working }\end{array}$ & $\begin{array}{l}\text { Menggelar } \\
\text { tikar }\end{array}$ \\
\hline 20. & $\begin{array}{l}\text { this goofy } \\
\text { little }\end{array}$ & $\begin{array}{l}\text { Someone } \\
\text { who is }\end{array}$ & $\begin{array}{l}\text { Pembuat } \\
\text { onar }\end{array}$ \\
\hline
\end{tabular}

\begin{tabular}{|c|c|c|c|}
\hline & stinker, & $\begin{array}{l}\text { mischievous } \\
\text { and ornery }\end{array}$ & \\
\hline 21. & So beat it. & $\begin{array}{l}\text { Face the } \\
\text { problem }\end{array}$ & $\begin{array}{l}\text { Hadapi } \\
\text { masalah }\end{array}$ \\
\hline 22. & $\begin{array}{l}\text { You're } \\
\text { holding up } \\
\text { the line. }\end{array}$ & $\begin{array}{l}\text { A temporary } \\
\text { state of being } \\
\text { that } \\
\text { recommends } \\
\text { that the } \\
\text { appropriate } \\
\text { position is to } \\
\text { remain } \\
\text { steady and } \\
\text { not react } \\
\text { whatsoever }\end{array}$ & $\begin{array}{l}\text { Menghalangi } \\
\text { antrian }\end{array}$ \\
\hline 23. & meter maid & $\begin{array}{l}\text { a woman } \\
\text { whose job is } \\
\text { to find } \\
\text { vehicles that } \\
\text { are parked } \\
\text { illegally. }\end{array}$ & Meter maid \\
\hline 24. & $\begin{array}{l}\text { I'd lose my } \\
\text { head if it } \\
\text { weren't } \\
\text { attached to } \\
\text { my neck. }\end{array}$ & $\begin{array}{l}\text { My memory } \\
\text { is so bad }\end{array}$ & Lupa ingatan \\
\hline 25. & $\begin{array}{l}\text { It's just, you } \\
\text { know it } \\
\text { burns me } \\
\text { up to see } \\
\text { folks with } \\
\text { such } \\
\text { backward } \\
\text { attitudes } \\
\text { towards } \\
\text { foxes. }\end{array}$ & Be angry & Naik darah \\
\hline
\end{tabular}

Translation of English Idiomatic Expressions in Zootopia Into Indonesian Context (Asti Ramadhani Endah Lestari) 


\begin{tabular}{|c|c|c|c|}
\hline 26. & $\begin{array}{l}\text { just a real } \\
\text { articulate } \\
\text { fella. }\end{array}$ & $\begin{array}{l}\text { Able to } \\
\text { express } \\
\text { thoughts and } \\
\text { feelings } \\
\text { easily and } \\
\text { clearly }\end{array}$ & Tipis bibir \\
\hline 27. & $\begin{array}{lr}\text { I'll } & \text { bite } \\
\text { your } & \text { face } \\
\text { off! } & \end{array}$ & $\begin{array}{l}\text { Really made } \\
\text { at someone }\end{array}$ & $\begin{array}{l}\text { Akan aku } \\
\text { kasih bogem } \\
\text { mentah }\end{array}$ \\
\hline 28. & $\begin{array}{l}\text { It's called a } \\
\text { hustle, } \\
\text { Sweetheart. }\end{array}$ & $\begin{array}{l}\text { pretend to } \\
\text { be a bad pool } \\
\text { player so that } \\
\text { people will } \\
\text { make bets } \\
\text { with you, } \\
\text { and then it } \\
\text { turns out } \\
\text { you're really } \\
\text { good and } \\
\text { you win their } \\
\text { money. }\end{array}$ & $\begin{array}{l}\text { Berpura-pura } \\
\text { jahat untuk } \\
\text { melakukan } \\
\text { kebaikan }\end{array}$ \\
\hline 29. & whoopsie & mistakes & $\begin{array}{l}\text { Tergelincir } \\
\text { lidah }\end{array}$ \\
\hline 30. & $\begin{array}{l}\text { Till finally } \\
\text { she has no } \\
\text { choice but } \\
\text { to go } \\
\text { back home } \\
\text { with that } \\
\text { cute fuzzy } \\
\text { wuzzy little } \\
\text { tail } \\
\text { between her } \\
\text { legs to } \\
\text { become. }\end{array}$ & $\begin{array}{l}\text { Cute little } \\
\text { bunny }\end{array}$ & Anak lucu \\
\hline 31. & Be careful & Lose your & Putus asa \\
\hline
\end{tabular}




\begin{tabular}{|c|c|c|c|}
\hline & & $\begin{array}{l}\text { extremely } \\
\text { untidy and } \\
\text { his office is a } \\
\text { complete } \\
\text { mess. }\end{array}$ & \\
\hline 39. & $\begin{array}{l}\text { I popped } \\
\text { the weasel! }\end{array}$ & $\begin{array}{l}\text { Catch the } \\
\text { weasel }\end{array}$ & menangkap \\
\hline 40. & $\begin{array}{l}\text { Shut your } \\
\text { tiny mouth } \\
\text { now! }\end{array}$ & Stop talking & Tutup mulut \\
\hline 41. & $\begin{array}{l}\text { All right, } \\
\text { well, I'd say } \\
\text { the case is } \\
\text { in good } \\
\text { hands. }\end{array}$ & $\begin{array}{l}\text { Is in the right } \\
\text { person }\end{array}$ & $\begin{array}{l}\text { Orang yang } \\
\text { tepat }\end{array}$ \\
\hline 42. & $\begin{array}{l}\text { But.. You } \\
\text { strike out, } \\
\text { you resign. }\end{array}$ & $\begin{array}{l}\text { You fail, you } \\
\text { resign }\end{array}$ & gagal \\
\hline 43. & $\begin{array}{l}\text { And time is } \\
\text { money. }\end{array}$ & $\begin{array}{l}\text { Time is } \\
\text { precious }\end{array}$ & $\begin{array}{l}\text { Waktu } \\
\text { adalah uang }\end{array}$ \\
\hline 44. & $\begin{array}{l}\text { Any moron } \\
\text { can run a } \\
\text { plate? }\end{array}$ & $\begin{array}{l}\text { It generally } \\
\text { describes a } \\
\text { process of } \\
\text { noting the } \\
\text { license plate } \\
\text { number, } \\
\text { looking it up } \\
\text { on } \\
\text { computer, } \\
\text { and using the } \\
\text { data there to } \\
\text { figure out the } \\
\text { name and } \\
\text { address of } \\
\text { the person } \\
\text { who owns }\end{array}$ & $\begin{array}{l}\text { Tidak dapat } \\
\text { diandalkan }\end{array}$ \\
\hline
\end{tabular}

\begin{tabular}{|c|c|c|c|}
\hline & & the car. & \\
\hline 45. & on the hook & $\begin{array}{l}\text { in hard } \\
\text { situation }\end{array}$ & $\begin{array}{l}\text { Di ujung } \\
\text { tanduk }\end{array}$ \\
\hline 46. & $\begin{array}{l}\text { We are } \\
\text { really } \\
\text { fighting the } \\
\text { clock } \\
\text { and every } \\
\text { minute } \\
\text { counts. }\end{array}$ & In a hurry & Tergesa-gesa \\
\hline 47. & $\begin{array}{l}\text { Darn it. It's } \\
\text { a bummer. }\end{array}$ & $\begin{array}{l}\text { A situation } \\
\text { in which no } \\
\text { desirable } \\
\text { result can } \\
\text { occur }\end{array}$ & $\begin{array}{l}\text { Tarik muka } \\
\text { dua belas = } \\
\text { kecewa }\end{array}$ \\
\hline 48. & $\begin{array}{l}\text { For old } \\
\text { times sake? }\end{array}$ & $\begin{array}{l}\text { in order to } \\
\text { experience } \\
\text { again } \\
\text { something } \\
\text { one did in } \\
\text { the past }\end{array}$ & mengulangi \\
\hline 49. & $\begin{array}{l}\text { We broke } \\
\text { bread } \\
\text { together. }\end{array}$ & $\begin{array}{l}\text { To engage in } \\
\text { a } \\
\text { comfortable, } \\
\text { friendly } \\
\text { interaction. }\end{array}$ & $\begin{array}{l}\text { Menjalin } \\
\text { hubungan }\end{array}$ \\
\hline 50. & $\begin{array}{l}\text { Scared my } \\
\text { driver half } \\
\text { to death. }\end{array}$ & Very scared & $\begin{array}{l}\text { Ketakutan } \\
\text { setengah } \\
\text { mati }\end{array}$ \\
\hline 51. & $\begin{array}{l}\text { Down on } \\
\text { all fours. }\end{array}$ & $\begin{array}{l}\text { both hands } \\
\text { and both } \\
\text { knees on the } \\
\text { ground }\end{array}$ & merangkak \\
\hline 52. & $\begin{array}{l}\text { I mean, } \\
\text { kid's turned } \\
\text { into one of }\end{array}$ & $\begin{array}{l}\text { Undergo } \\
\text { nature }\end{array}$ & $\begin{array}{l}\text { Menjelajah } \\
\text { alam }\end{array}$ \\
\hline
\end{tabular}

Translation of English Idiomatic Expressions in Zootopia Into Indonesian Context (Asti Ramadhani Endah Lestari ) 


\begin{tabular}{|l|l|l|l|}
\hline & $\begin{array}{l}\text { the } \\
\text { top pastry } \\
\text { chefs in the } \\
\text { tri-burrows. }\end{array}$ & & \\
\hline 53. & I thought & Unaware of & Besar mulut \\
she was & what she & \\
talking in & says & \\
tongues or & & \\
something. & & \\
\hline
\end{tabular}

From the table shown, we can conclude that translating idiomatic expressions is a complicated process. A translator must have the knowledge about linguistics and sociopragmatics in both source language and target language. Idiomatic expressions are closely related to the culture. The above data showed that there is an English idiom which can not be translated in Bahasa Indonesia. The idiom Meter maid refers to a police officer whose job is to find vehicles that are parked illegally. That kind of job is a duty of a department of transportation officer not a police officer. Therefore, instead of translating the word meter maid into police officer or transportation officer, the researcher decided to adopt the word itself.

The above table showed that there are four English idiomatic expressions that have the similar form of idioms in Bahasa Indonesia:
a. You're holding up the line= menghalangi antrian
b. Time is money $=$ waktu adalah uang
c. Scared half to death = ketakutan setengah mati
d. Shut your tiny mouth = tutup mulutmu

Many English idiomatic expressions have the equal meaning but different form of idiom in Bahasa Indonesia. For these types of idiom, the researcher applied the idiomatic translation method. For example:

a. bunny bumpkin = otak udang

b. one thousand foot fall = omong kosong

c. carrot baby $=$ Anak ingusan

d. $\quad$ Frigid ice wall $=$ Peti es $/$ berat bibir

e. $\quad$ Filthy toilet $=$ Bunga tidur

f. he cheats like there's no tomorrow $=$ akal bulus

g. Don't lose your key = Jangan sampai hilang arah

h. Greasy walls $=$ penipu ulung

i. $\quad$ Top of my class $=$ bintang kelas

Other English idiomatic expressions do not have the equal meaning in Bahasa Indonesia idiom. Therefore, the researcher decided to adapt the free translation method for these types of idioms. For example:

a. before you hit the streets = sebelum berangkat kerja

b. scorching sandstorm = hari yang sangat panas

c. fuzzy bunny $=$ anak malas

d. played cribbage $=$ mudah ditipu

e. a proud-scared combo $=$ sangat menakutkan

f. it's called a hustle = berpura-pura jahat untuk melakukan kebaikan

The description above proved that idiomatic expressions are closely related to social context of a language. In order to make the translation accurate, natural, and effective, 
the translator should applied various translation methods. The translator has to master not only the linguistics aspects but also the sociopragmatics contexts of a language. These knowledge will guide the translator in making decision of which version of the translation will be taken.

\section{CONCLUSION}

Translation study is a multidisciplinary field which involve linguistics and other relevant subjects related to the text that is being processed. One text that is likely to be translated is idiomatic expressions. Idiomatic expressions are translated not only in interlingual translation but also in intralingual translation. Idiomatic expression is a fixed phrase that has the unpredictable meaning that the meaning differs from the actual meaning.

The result of the study revealed that four English idiomatic expressions have the similar form and meaning with Bahasa Indonesia idioms. Many of the English idioms have the equal meaning of idiomatic expressions but appear in different forms. Other idioms do not have the idioms with equal meaning, thus they were translated by using free translation method. Finally, there is one English word adopted in Bahasa Indonesia since this word refers to a job that does not exist in Indonesian context, meter maid.

\section{REFERENCES}

Bradeau, Ligia. (2012). Defining features of idioms: 'Stumbling Blocks' in the process of translation. Studia UBB Philologia, LVII, 3, 2012.

Candra, Eva Nurul dan Asti R E Lestari. (2016). Proverbs in use: a study of speech acts in pragmatics. Proceeding Seminar Internasional Linguistik Interdisipliner. Universitas Indonesia

Cao, Deborah. (2007). Translating law. Clevedon, Buffalo, \& Toronto: Multilingual Matters Ltd.

de Matos, Gomez. (2006). Language and creativity: the art of common talk (Book Review). Essential Teacher. Cambridge: Cambridge University Press

Emzir. (2015). Teori dan pengajaran penerjemahan. Jakarta: Raja Grafindo Persada

Griffin, Patrick. (2006). An Introduction to English Semantics and Pragmatics. Edinburgh. Edinburgh University Press

House, J. (2014). Translation: a multidisciplinary approach. New York: Palgrave Macmillan.

Hufford, James, Heasley, Brendan, and Smith, Michael. (2007). Semantics; a course book second edition. New York. Cambridge University Press

Langlotz, Andreas. (2006). Idiomatic creativity: a cognitive-linguistics model of idiomrepresentation and idiom-variation in english. Philadelphia: John Benjamins

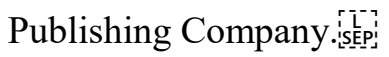


Munday, Jeremy. (2011). Introducing translation studies: $2^{\text {nd }} e d$. New York: Routledge

Nida, E. (2011). Contexts in translating. Amsterdam: John Benjamins Publishing Company.

Nugraha, Indra. (2016). Inappropriate translation of english cursing on box office films on movie theatre and $t v$ and its relationship with KPI's broadcasting standard program along with viewers' understanding towards cursing. Proceeding Seminar Internasional Linguistik Transdisipliner. Universitas Indonesia

Pamungkas, Muhammad Ersan. (2016). Legal translation as a multidisciplinary linguistic practice. Proceeding Seminar Internasional Linguistik Transdisipliner. Universitas Indonesia. 